\title{
Assisted Suicide in Italy: Constitutional right or wishful Thinking?
}

\author{
Carlo Casonato* \\ Professor of Law, University of Trento, Italy \\ *Corresponding author: Carlo Casonato, Professor of Law, University of Trento, Italy \\ To Cite This Article: Carlo Casonato. Assisted Suicide in Italy: Constitutional right or wishful Thinking?. Am J Biomed Sci \& Res. 2019 - 3(6). \\ AJBSR.MS.ID.000734. DOI: 10.34297/AJBSR.2019.03.000734
}

Received: June 17, 2019 | Published: July 11, 2019

\section{Opinion}

Italy could soon join the group of states that, under certain conditions, allow assisted suicide.

The Constitutional Court, in fact, has set for next September 24th the hearing for officially dealing with the constitutional legitimacy of the article of the criminal code that prohibits, in absolute terms, any activity of abetting suicide. However, already in a previous hearing, the Court anticipated that this prohibition is unconstitutional (order no. 207, October 24th, 2018). The case came before the Constitutional Court following the indictment of Mr Marco Cappato for having helped Mr Fabiano Antoniani (known as DJ Fabo) commit suicide.

DJ Fabo was rendered blind and quadriplegic by a car accident in 2014. He could breathe autonomously only for short periods and was therefore mechanically ventilated. He was fed artificially and, quoting the Court itself, he "suffered particularly intense physical pain caused by daily muscle spasm and cramps." DJ Fabo could have asked for the withdrawal of mechanical ventilation or artificial hydration and nutrition (in Italy, the right to refuse medical treatment is formally recognized by law n. 219/2017). Due to his particular condition, however, DJ Fabo would have spent a few days or even weeks before dying of suffocation or dehydration. Faced with this prospect, which DJ Fabo considered contrary to his dignity and a cause of suffering for himself and his loved ones, he decided to commit suicide. Because of his paralysis, he asked Mr Cappato (the leader of an association campaigning for legal euthanasia) to take him to the Swiss clinic Dignitas, in order to be assisted in suicide (a practice permitted there).

Returning from Switzerland, Mr Cappato was indicted for abetting suicide, a conduct that in Italy is punished by the criminal code (Art. 580) with a penalty of up to 12 years in prison. The Constitutional Court, asked to establish whether this prohibition is contrary to the Constitution, set the hearing for the official discussion of the case on September 24, 2019, already indicating, in the preliminary October 2018 hearing, three reasons for the constitutional illegitimacy of the unconditional ban on assisting suicide. The three reasons revolve around a) the need to save seriously ill persons from suffering,

b) the principle of non-discrimination against some patients,

c) the respect for self-determination of adults and competent persons.

The Court of Rome, in the first place, recognized that preventing DJ Fabo from being assisted in suicide forced him to withdraw the mechanical ventilation or the artificial hydration and nutrition. In this way, however, he was forced to "undergo a slower process, in a scenario that does not correspond to the patient's vision of a dignified death and which is marked by pain and suffering for people close to the patient." Secondly, the Constitutional Court acknowledged that life is an asset that the State must protect. However, given that every patient has the right to refuse lifesaving and life-sustaining treatments, thus resulting in death, the judges wondered why the will of those who ask for assisted suicide should not be respected. If "the primary importance of the value of life does not rule out the duty to respect the patient's decision to end his or her life by means of suspending healthcare treatments there is no reason for the same value to become an absolute obstacle, supported by criminal liability, to accepting the patient's request for assistance in avoiding the slower decline - perceived as running contrary to their idea of a dignified death - which results from the suspension of life support devices".

Thirdly, the Court underlined the right of seriously ill people to decide about ending their life in a dignified way, unwilling to claim that the illness-driven vulnerability produces an inability for self-determination. Referring to the principle of equality, the Court wrote that "if people kept alive by artificial life support treatments are considered under the system to be capable, under certain conditions, to decide to bring an end to their lives by suspending this treatment, there is no clear reason why the same person should instead be considered to be in need of unyielding and indiscriminate protection against their own will when it comes to the decision to end their lives with the help of others, when they consider this option to be more dignified than the aforementioned suspension 
of treatment". This kind of reasoning is not new in comparative law. Similar motives are already found, for instance, in a 1997 Colombian Constitutional Court ruling (C-239/1997). And the Supreme Court of Canada, in Carter v. Canada (2015 SCC 5), used similar reasons to hold the prohibition of assisted suicide as contrary to the Canadian Charter of Rights and Freedoms.

Borrowing a model used by the Canadian Court itself, furthermore, the Italian Constitutional Court made a rare use of its procedural powers. For the very first time, it suspended the hearing and postponed the final judgement for one year (to next September) in order to give lawmakers time to enact a comprehensive law. As a result of the Italian ruling, however, three problems emerge. The first one concerns the Parliament, which, despite having held a few hearings, has not yet begun a thorough and deep examination of the subject. The first risk is therefore that, without a law, the Constitutional Court, at the next September hearing, will have to shape a regulation, through its decision, to a complex and ethically sensitive topic such as assisted suicide - a topic that should instead receive proper attention by Parliament. The second problem concerns the conditions that the Court has set in order to obtain assistance for suicide. In addition to the three requirements common to the jurisdictions allowing assisting suicide (the ability to make a free and informed decision; an incurable and serious disease; physical or psychological intolerable suffering) the Italian judges added a fourth condition: the presence of a life support treatment. This requirement is problematic as many patients (such as Glorya Taylor, for instance, plaintiff in Carter v. Canada) ask for an aid in their suicide before being treated with mechanical ventilation or artificial nutrition and hydration - and sometimes, precisely because they do not want this kind of life-sustaining treatments.

Forcing them to have a tracheostomy or ANH only for the purpose of accessing suicide assistance seems highly unreasonable. The third problem deals with the Hippocratic principle 'First do not harm'. In fact, the Italian code of medical ethics, like many others, provides for the express prohibition of performing "acts aimed at causing the death of the patient". In the absence of a (so far improbable) amendment of the code, therefore, from next September onwards, a patient will be entitled to the constitutional right to be assisted in suicide, but no doctor will be able to aid him, because of the deontological ban. It is good news that the Italian Constitutional Court has already anticipated, and will soon officially declare, that competent, sick and suffering people who make a free and informed decision about their suicide are entitled to thirdparty assistance. In the complexity of the legal system, however, this right is likely to remain, at least for a while, wishful thinking. 